\title{
The Introduction of Elements of Dual Education System: Experience, Problems, Prospects
}

\author{
S. Kh. Muhambetaliev' and A. Kh. Kasymova ${ }^{2}$ \\ 'Ural College of Gas, Oil and Industrial Technologies, Uralsk - 090000, Kazakhstan; akm.kasymova@gmail.com, \\ ${ }^{2}$ West Kazakhstan Agro-Technical University named after Zhangir Khan, Uralsk - 090000, Kazakhstan; \\ s.muhambetaliev@mail.ru
}

\begin{abstract}
Objectives: The main aim of the research is to study the peculiarities of the organization of educational process in the dual training of students. Methods/Statistical Analysis: Research methods can be divided into two categories: 1. Theoretical: systematic analysis, synthesis, generalization, analysis of philosophical, pedagogical, psychological, methodological and technical on the research problem, and 2. Experimental: observation, conversation, monitoring, survey, and testing, pedagogical experiment. In the research process introducing innovative techniques that are used during lectures, seminars, workshops, business games, projects, simulation modeling of problem situations, thematic conferences with the participation of employers. Findings: They are identified in the loss of distinctive characteristics of dual and traditional system of training. Special attention is paid to the dual system of education in Germany, which has passed a long historical inspection and demonstrates a high quality of education, as well as the relevance, perspectives and advantages of such education in Kazakhstan. List the tasks that need to be addressed for the development of the education system in a dual format. It is concluded that, despite some shortcomings, the dual system of education is one of the successful models of cooperative learning and production, which can be used as an innovative type of organization of target training. The main aspects of the organization of dual target training of specialists in the conditions of interaction between educational institutions and enterprises - customer's frames were considered. Interest and the organization of training in the enterprise, vocational education in the dual system aims to form special knowledge, skills and abilities necessary to perform skilled professional activities. Application/Improvements: The results of this study can be applied pedagogical staffs of educational institutions of technical and vocational education, as well as representatives of employers implementing the dual training system.
\end{abstract}

Keywords: Dual Education System, Education in Kazakhstan, Educational Institutions, Professional Knowledge, Training

\section{Introduction}

Currently, the main trend in the world educational space is the development of innovative education, which is aimed at the formation of professional knowledge and skills and actual competencies required in the formation of a new, high-tech products. The most important qualitative characteristic of the present stage of development of the vocational education system are the integration processes, which reflect, on the one hand, substantial structural changes within the actual system of education, and on the other the processes of interaction between professional education and the production sector ${ }^{1}$.

The New political course of the Strategic Plan for the development of the Republic Kazakhstan for 2011-2020

${ }^{*}$ Author for correspondence 
and "Kazakhstan-2050" is aimed at strengthening the intellectualization of human capital by providing access to education and improving its quality. In modern conditions, one of the global solutions of the system to improve the quality and competitiveness of human resources in the Republic of Kazakhstan is to maximize the practical implementation of a dual mechanism of learning in the national education system. This approach has been widely used in educational practice in Germany ${ }^{2}$. The main problem of modern education in Kazakhstan is the isolation of theoretical knowledge gained by the student in a college, from the production of the reality that they face after graduation. Even the most diligent student is not ready to solve the tasks set before him by the employer. This is due to the fact that the theory obtained in school, is just a set of terms and formulas, if it is not backed by practice. But a dual system has a great advantage as it's a system of training which combines workplace experience and practice with vocational college based education ${ }^{3,4 .}$

The discrepancy between theory and practice is necessary to eliminate the enterprise. Young professional, having a job, is forced within 2-3 years to learn the specifics and the basics of production, to acquire new knowledge and necessary skills. Such additional training requires additional costs for the company, and therefore, the employer of such a learning process is not profitable. The employer easier to hire someone with experience, who will not need additional time to obtain the necessary skills, thus it appears that the countries are unemployed young people and at the same time a shortage of labor ${ }^{5}$. Scholars and practitioners, as evidenced by the analysis of domestic and foreign sources, are active in the search for new educational models that will allow reorienting occupational education in its content, organizational, technological aspects in the satisfaction of important socio-economic needs. At the same time optimal use in educational activities a variety of innovative, methodical, conceptual-theoretical and didactic, development, accumulated in vocational pedagogy over the last decade $e^{6}$. One of the principal of the dual system is to provide "broad basic vocational knowledge" and the knowledge and technical skills which are important for a occupational activity ${ }^{?}$.

Educational institutions of Europe have long used effective way of training highly qualified specialists, namely, a dual system of education. Employers often complain about the lack of technical skills of their young employees and the dual system can be the solution of increasing the technical knowledge of the young ${ }^{\underline{8}}$. The introduction of dual training contributes to solving the basic problem of vocational education - the gap between theory and practice ${ }^{\text {. }}$.

The analysis of the situation currently abroad on introduction of dual education system shows that the dual system of education being implemented in some countries, especially in Germany, Austria, Switzerland, Denmark, the Netherlands and France, Croatia, Serbia, Slovenia, Macedonia, Montenegro, recent years in China ${ }^{10}$ and other Asian countries ${ }^{11}$.

The management structure and content of vocational education are serious differences in various countries in the European Union:

- dual system in Germany - vocational training, regulated corporate principles, this unique educational model is a key reason the country has the lowest unemployment rate in Europe for people under 25 7.6 percent $\frac{12,13}{}$.

- professional training in France, vocational training, regulated by the state management principles.

- the British system of national vocational qualificationsvocational training, regulated by strict principles of market economy ${ }^{14}$.

The undisputed leader in the organization of the dual training system is Germany, where vocational education has distinctive features - a well-developed mentoring, training, practice-oriented, active participation of business in training. The country's experience serves as an example for the whole of the European Union.

Vocational trainings in the dual system originated in Germany. This training is based on the interaction of two distinct areas: organizational and legal, within the framework of officially recognized vocational training, which is carried out according to the legislation on vocational education. This system comprises two different training and production environment: private enterprise and public vocational school, which operate with the aim of professional training of students ${ }^{11}$.

Enterprises in Germany that are implementing the dual system, suggesting their involvement in the process of training, go on a fairly large costs to train employees, because we believe that these costs are of sufficient quality vocational training will be a reliable contribution of capital. In addition, companies are also interested in learning outcomes, and in its organization, content, etc. This explains the importance of the dual system as a model of 
professional training, allowing coping with the gap, the discrepancy between industrial and educational spheres in issues of professional training 15 .

The analysis of the works of German researchers shows that the dual system ensures a close relationship and interaction of professional education with the production sector, timely response to changing needs and trends.

For national vocational education one of the urgent issues is the establishment of a close relationship with the production sector.

In this regard, the promotion of the principles of the dual organization of education, especially at the level of technical and vocational education, it seems appropriate, timely and perspective ${ }^{16}$.

The experience of dual training is currently actively studied in Kazakhstan, creates a legislative and regulatory framework for the development of dual (cooperative) learning: the Law of RK "On education", State program of education development in the Republic ${ }^{17}$.

\subsection{Practical Significance}

The results of this study can be applied pedagogical staffs of educational institutions of technical and vocational education, as well as representatives of employers implementing the dual training system to prepare mid-level professionals.

Experience and perspectives of dual training in this article - as one of the perspective models of training and industry integration can be used as an innovative type of organization targeted training in technical and vocational education and created organization in our country that leads and coordinates the work in this direction (Management methodology dual training system) will allow to develop common standards for the creation of the Kazakh model of dual training.

The introduction of elements of dual training in the Ural College of gas, oil and branch technologies meet modern challenges of the society is the international experience contribution in the future.

\subsection{The main Directions of the Implementation of the Dual Training System in Kazakhstan}

To solve the tasks set by the President of the Republic on creation of the Kazakh system of dual training, work is carried out in the following areas:
- improvement of material and technical base of colleges. Over the last 3 years on the development of technical and vocational education system is allocated more than 14 billion tenge, including the modernization of material and technical base, to 1.8 billion;

- introduction of innovative technologies for the preparation of the labor demanded by the market experts. Using the "Bilim al" automated control system makes it possible to bring information and education services to each participant in the educational process ${ }^{\frac{18}{}}$;

- the use of educational technology, developed by the German company ${ }^{19}$; and

- improvement of social partnership through the implementation of the dual system of vocational training.

\subsection{The Experience of Introducing Elements of the Dual Training System in the Ural College of Gas, Oil and Branch Technologies}

The introduction of elements of dual training in the Ural College of gas, oil and branch technologies meets the requirements of modern society, foreign experience is used and also the experience acquired by the teachers in the process of foreign training. The main stages are allocated:

1. preparatory stage is the implementation of the dual system of education through:

- preparation of regulatory documents;

- the development of educational programs of study for particular faculties;

- signing contracts with companies; and

- the establishment of contingent of students.

2. organizational stage involves:

- identify ways of training for the established professions;

- preparation of class schedules; and

- monitoring of learning outcomes.

3. final stage includes:

- pilot test training of the students in this learning system;

- systematization, generalization of the study results; and

- data processing, introduction of results into practice. 


\subsection{The Expected Results of the Implementation of the Dual Training System}

The expected results of the implementation of the dual training system are as follow:

- the formation of competences that allows to choose a profession consciously;

- growth of demand for graduates in the labor market, trained in the dual system;

- improve the quality of training of students;

- development of interaction between educational institutions and enterprises by involving them at the stages of implementation of the program;

- vocational training according to the requirements of employers;

- reducing unemployment among young people ${ }^{20}$; and

- improving the competitiveness of the College.

Thus, from educational institutions are required to ensure high quality training, relevant to modern production, experts qualitatively perform their work with a high level of proficiency in the theory and practice of production.

\section{Research methods}

Research methods can be divided into two categories:

1. Theoretical: systematic analysis, synthesis, generalization analysis of philosophical, pedagogical, psychological, methodological and technical on the research problem.

2. Experimental: observation, conversation, monitoring, survey, testing pedagogical experiment.

In the research process introducing innovative techniques that are used during lectures, seminars, workshops, business games, projects, simulation modelling of problem situations, thematic conferences with the participation of employers.

\section{The Main Results}

Purpose - to study the peculiarities of educational process organization, the introduction of dual training. Confirmation of the effectiveness of elements of the dual training with the aim of quality training in educational institutions of technical and vocational education.

Objectives of the study are:

firstly, to build a new model of training that can overcome the lack of quality of labor resources from the requirements of the modern labor market ${ }^{21}$;

secondly, to address the issues of training, meeting the requirements of employers and employment of graduates Scientific novelty of the research lies in the fact that:

- marked the system of scientific and methodological support of dual task training, which includes the design and argumentation of the content, methods and forms of its realization; the achievement objectives, learning content in the learning process; the tracking of current and final results of study;

- is justification given for the participation of the social partners in the selection and structuring of the content of training of future specialists; and

- deals with the importance of sectoral and functional specialization in the acquisition of additional knowledge and skills that will be necessary for the formation of professional functions defined specific content and nature of work of a specialist.

The theoretical value of the study lies in the modernization theory of professional education, namely, the development of the dual vocational training system:

- established a set of principles on a theoretical level that are based in training in the dual system of education. Given specific forms, methods, learning tools that help students to learn specific content in a specific field of knowledge and professional activity (the priority of the quality of training, improvement of professional orientation of content of education; the joint activities of educators, employers and other social partners; and

- created, argued and tested methods and techniques activities of teachers and students at the methodological level. The use of these methods and techniques aim at the mastery of the training content; training program documentation on the basis of new state educational standards; teaching SGES; means of control, guidelines.

Practical value of the study include:

firstly, the development, substantiation and introduction in educational process of educational planning, educationalmethodical documentation in the dual system training; 
secondly, the development and implementation of contractual obligations of the parties for the organization of serial mode processes of theoretical and practical training, problem solving on the use of students in the workplace.

The proposed adjustment of curricula, work programs, the structure of training and production activities of students according to specifics of the actual conditions of dual task training. Identified key area of collaboration for college and enterprise for the improvement of training and student's examination as well as protection of graduation.

Currently, it is obvious that the implementation of important socio-economic goals depends on productive use of labor, transformation of the structure improve the quality of workforce and quality vocational education. Vocational education ensures the training of young professionals for life, ensures the future success of each life, the country's success and the success of society as a whole.

The most important qualitative characteristic of the present stage of development of the vocational education system are integration-wide processes, which reflect, on the one hand, substantial structural changes within the actual system of education, and on the other, the relationship between professional education and the production sector.

In the message of the Head of the State N. A. Nazarbayev "Kazakhstan's Way-2050: common goal, common interests, common future" the goal in the next 2-3 years, to form the nucleus of a national system of dual technical and vocational education. In order that the state became the guarantor of young people receiving technical education ${ }^{22}$. Close cooperation between the business world and government is characteristic of the dual vocational training system ${ }^{23}$.

Such institution in our region is the Ural College of gas, oil and branch technologies. Ural College of gas, oil and branch technologies is the oldest educational institution which provides training in 15 specialties of the 10 technical areas. The transition to dual education model started in 2012. Under the dual education understand the optimal combination of theoretical and practical training in the college and in the enterprise. Thanks to the dual system of education students receive better knowledge and skills for their chosen profession. In other words it is a system in which trainees most of the training time is devoted to practice on the enterprise, where they will work after the college graduation. And the practice of European countries proves the fact ${ }^{24}$.

The effectiveness of the training in this case is the fact that the acquired theoretical knowledge is fixed in the process of practical work: training in the laboratory and during industrial training.

This system of education is considered as the most effective, and a student will gain professional knowledge at the expense of an optimum combination of theoretical and practical training, because $70-80 \%$ of the time it is trained directly on the production, and only $20-30 \%$ in College ${ }^{25,26}$.

This gives a number of advantages. Here are some of them: first, the training best meets the demands of modern production, and the employer will be able to get exactly this kind of specialist, what he needed. Secondly, students are interested in gaining deeper knowledge and strive to stay on the enterprise after training. This indicates a high level of motivation. The model stimulates students to carry out investigations to satisfy their need to know, then links the new knowledge into their thinking and decision-making processes ${ }^{27}$.

Thirdly, guaranteed higher than previously, the level of demand for graduates and their employment. It will provide significant socio-economic effect across the country.

In the end, we have the opportunity to enter the merging of business interests, graduates of technical and vocational education and the state, and it's a whole new level of tripartite partnerships.

With regard to the experience, it is necessary to note the following that for two years we studied the experience of foreign countries introducing the system of dual training, and experience of leading national institutions. As an example, was taken vocational education system in Germany, which is the leader in terms of skills (the evaluation of the International Institute of monitoring the quality of the workforce), and the dual education system of this country in most cases is considered a model for the whole European Union $\underline{28}$.

Using the example of the German model of dual training ${ }^{29}$ we understand that it is a good source of skilled workers and contributed to the progressive development of industry and economy. However, there are still questions which await solution, for example, necessary changes in the education system in Kazakhstan. And to resolve such issues is necessary, and seek as quickly as possible. To carry out in parallel the theoretical and practical training of students is necessary and useful. This allows 
us to solve several problems. First, in practice the student receives their first production experience. Upon completion of your studies in the school the young specialist is easier to get a job. Secondly, this approach to training will provide the enterprise with qualified personnel ${ }^{30}$.

We have the first results of joint training of specialists for LLP "Ural transformer plant" in the amount of 28 persons on two specialties: the collector and transformer winder winding high and low voltage.

The next step in the implementation of the joint plan of interaction of the enterprises of the Ural College of gas, oil and branch technologies in the provision of practiceoriented training of specialists, the implementation of dual education was the opening of the training ground in three fields. It will enable students to obtain basic skills in the chosen specialty will help teachers to accurately recreate the real situation in the workplace. The training ground is represented by several sites in three specialties, so the landfill, specialty "Electric power Supply" will allow students, engineering profession, in practice, to acquire knowledge of modern equipment, to study at the master classes of specialists.

On the ground in the field of "Construction and maintenance of gas - oil pipelines and storage" and "Operation of oil and gas fields" presented the equipment used by oil and gas enterprises in the production process. The presented equipment today serves as visual material for students who will contribute to the formation of ideas about the processes of production, processing and transportation of oil.

The training ground is a lab on the street for the student internships (practical training).

Thus, the creation of a training ground is not only the embodiment of the plans and plan sections, and one of the facts the prospects for the development of the dual training in the Ural College of gas, oil and branch technologies, effective collaboration, education and industry in the implementation of the dual training project.

One of the most effectives forms of training of young specialists - the dual system of training. And the reason is that it meets the interests of all parties involved companies, workers and the state ${ }^{31}$.

For companies, the dual training is a good opportunity to prepare footage for sure "custom" thus it will be ensured that the requirements of the enterprise, this results in savings of expenses for search, selection of specialists, their retraining and adaptation. Moreover you can select the best students ${ }^{32}$.
In addition, the above approach encourages students to learn in new ways. Prepared in dual education graduates are able to work with absolute dedication and performance, as already well aware of the enterprise's life and feel it is "their". This contributes to the consolidation of personnel and reduce turnover, which is extremely important for the production.

One of the most important tasks to be tackled by the Kazakhstan system of education is the formation of a new model of professionals training. This model should be able to overcome the mismatch in the structure, amount and quality of labor resources. The experience of Germany in the development of the dual training system can be very useful ${ }^{3}$.

The dual system of education won global recognition, as it is a common and recognized form of training.

Notes several advantages of the dual training system in comparison with the traditional:

- dual system in the training eliminates the shortcoming of traditional learning as the discrepancy between theory and practice;

- dual training system provides for the impact on the identity of the expert and the formation of a new psychology of the future specialist;

- training in the dual form promotes high motivation to acquire knowledge and skills in work;

- the head of the concerned institution interested in acquiring practical skills in your specialist;

- institution, working in Union with the customer, takes into account the requirements that apply to future professionals in the learning process $s^{34}$;

Ural College of gas, oil and branch technologies joined the group of colleges in the Republic, participating in the development of the Kazakhstan model of dual education. Currently we have shifted to dual training, the following specialty: "Veterinary", "Electric Power Supply ", "Construction and maintenance of gas - oil pipelines and storage", "Petroleum refining and gas process", "agriculture" and "Industrial and civil engineering". In a pilot project on dual training involved 299 people. With the 2013-2014 academic years the College identified an experimental platform of the Ministry of education and science of the specialty "Electric Power Supply". In the direction of the Department of education, several teachers have been trained in Singapore, Germany, Turkey and now two people studying in the UK. 
The College established a Coordinating Council for the implementation of dual forms of training, which included leading specialists of organizations and enterprises, interested in the quality of trained specialists of their industry. Also, a working group on the development of training documentation signed a tripartite cooperation agreement with the company and "Samruk-Kazyna" - JSC “inter Gas Central Asia” in 2013.

As the system operator of involving employers in training of specialists of the Ministry of education formed the holding company "Kasipkor" and at the suggestion of the Department of education Ural College of gas, oil and branch technologies is the core enterprise of the Holding.

When the dual system of education, especially increasing the value of social partnership as part of the investment enterprises and business - structures in the future will provide an opportunity to significantly improve training and to ensure that it meets the needs of the labor market. The College has been adequate experience of cooperation with the social partners ${ }^{35}$.

Thank to the generalization of practical experience formed the basis of the theory of social partnership in the sphere of professional education ${ }^{36}$. Social partnership is a special type of interaction between educational institutions with all actors of the labor market, its institutions, territorial authorities, institutions of society, public organizations, aiming at the optimal coordination and implementation of interests of all participants in this process. To improve the work-efficacy we must consider that the key factors are in the process. We think the students' competencies are one of the main factors. To improve the efficacy of dual training we should develop our students' generic and specific competencies. This work splits between the two partners of the dual training both the college and the firms take part in the development, so it is essential to harmonize their work in this field ${ }^{37}$.

The importance of the educational component in social partnership and leading role of the educational factor in the emergence of the phenomenon of social partnership is acknowledged in the scientific. In particular, underline the fact that the transition to social partnership was largely determined by the needs of investment in "human capital".

Social partnership, according to most scientists, is the most effective means of formation and realization of state policy in the field of vocational education. Social partnership provides a reliable connection between educational institutions and enterprises, which is based on mutual benefit and interest with the active participation of the state $^{\frac{38}{}}$.

To cooperate in the preparation of demanded experts who possess knowledge of modern information technology, further development and strengthening of equal and mutually beneficial relations in the implementation of the message of the President of the country for the development of vocational education and industrialinnovative development of West Kazakhstan region, our College has signed agreements providing for cooperation with leading enterprises of city and region. For a long time the leading social partners of the College are: the company "KPO b.v.", "Management of main gas pipelines "oral" JSC, Condensate JSC Zap.KAZ. REK", JSC Translating", LLP "Alau"”, "state enterprise" Ural Selkhozopitnaya station", Aidana LLP,LLP "Oral Terminal".

About the growing role of the social partners is demonstrated by the fact that at the initiative of the chamber of entrepreneurs of West Kazakhstan region signed 3 way agreement on joint activities according to the dual training between the Chamber of entrepreneurs of West Kazakhstan region, College and JSC "Zap.KAZ.REK", JSC "INTERGAS Central Asia", SD "Department of education of West Kazakhstan region" and the College; JSC "Republican scientific - methodical center of development," GU "Department of education of West Kazakhstan region" and the College; JSC "national training center "Orleu" "Institute of qualification increasing of pedagogical workers in WKO", SD "Department of education of West Kazakhstan region" and the College. With the aim of providing methodological assistance and organization of training course of teachers on introduction of dual system of education signed the tripartite agreement with the branch of ncpd "Orleu” IPK PR.

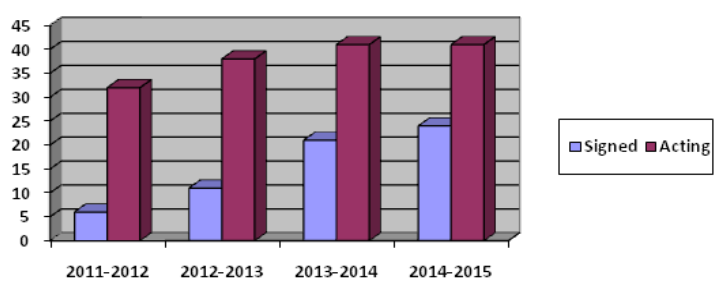

Figure 1. Diagram of the number of agreements with social partners during 2012-2015.

In Figure 1 shows that currently, the College has concluded agreements on cooperation with more than 40 
enterprises of the region. And indicators of fruitful work with the social partners are victory of the College over the past two years, the regional competition "the Best social partnership".

As noted above, in dual training needs to be engaged enterprise, we signed a contract to expand cooperation by:

- joint development of curricula,

- assist in the logistics, and

- organization of training, production practices.

The social partners participate in the work on development of curricula content and programmes based on modular training. In accordance with the requirements of the technology of dual training number of hours of theoretical load over a number of disciplines was reduced by $1 / 3^{39}$.

Practical and laboratory classes in core subjects have been transformed in the course (semester) development, which reflect the use of theoretical models in the implementation of practical tasks. This has allowed for an increase in hours for technology and professional practices. According to the results of educational practice for students who passed the exam, is assigned to the working profession.

We are also considering the possibility of introducing some integrated courses, e.g. a course on "Mechatronics". This course involves the study of the integration of disciplines, "Technical mechanics", "electronics" and "automation". For the course "mechatronics" two of our teacher passed courses in Singapore on "Technologies of mechatronic systems".

For students have mastered the new technologies in the oil and gas, construction industries and agriculture we are attracting leading specialists of enterprises as teachers for reading of special courses and lessons of industrial training, as well as managers of industrial practices, leaders and reviewers of diploma projects, the Chairpersons of the state commissions and the qualifying exams.

Thus, as shown in Figures 2-4, with the dual target training, already in the early stages of learning the student acquires certain professional competence. This arrangement gives him the opportunity to rethink future profession and to make an informed decision about the correctness of choice of profession.

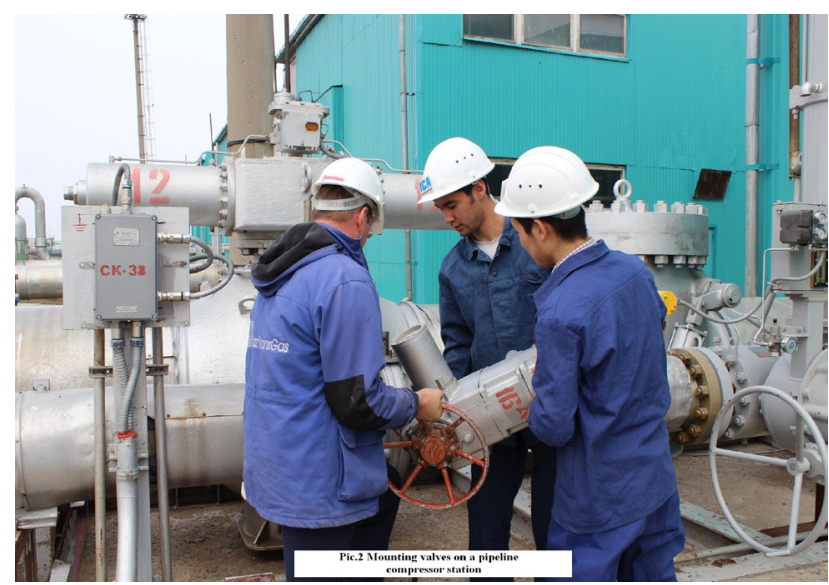

Figure 2. Mounting valves on a pipeline compressor station.

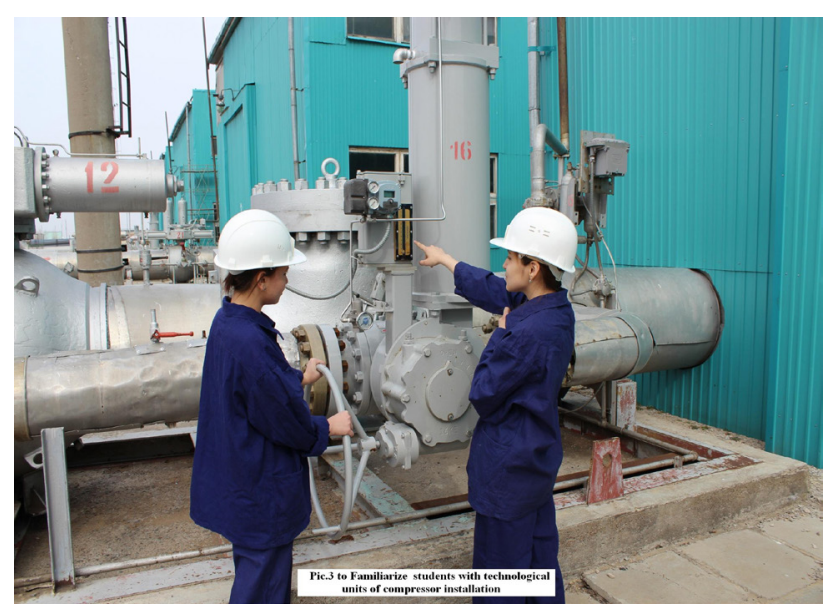

Figure 3. Familiarizing students with technological units of compressor installation.

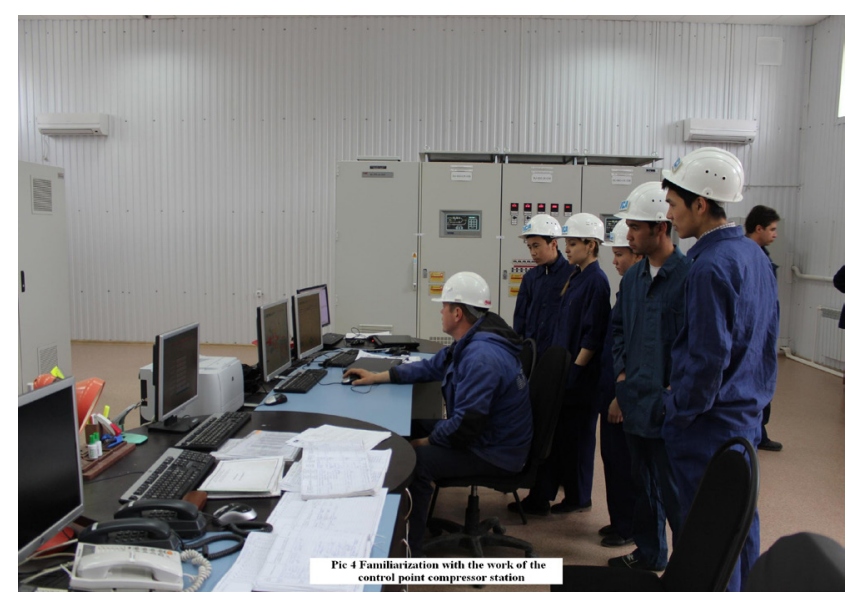

Figure 4. Familiarization with the work of the control point compressor station. 
Today the social partners are involved in the organization of educational process in College. Education on the examples of personalities famous people associated with the enterprises develop in the students team spirit, is of interest to the enterprise. To improve cooperation with customers personnel hold job Fairs, "open Days", where College graduates share their achievements, are interested in employment.

\section{Discussion}

Issues of improvement of relations with social partners, organization of production practices, implementations of elements of the dual forms of learning are regularly highlighted in the media: TDK 42 TV channels, Kazakhstan - Oral; the magazine "Technical CPT zhaneBilim"; the newspaper "Priurale", "Oral oniri", "Zhayikuni" etc.

With the aim of expanding the boundaries of cooperation to improve the system of dual training, entering the joint action of the TPE and employers on the training of mid-level professionals, in demand of workers, employment of College graduates the TV channel Kazakhstan - Oral invited the College to participate in "Teleconference", devoted to the Issue of introduction of dual forms of training", in the discussion which was attended by organizations in the education of Atyrau, Mangistau and Aktobe regions.

The interaction between the College and businesses in the issues of creating conditions for training of specialists affected the growth of the quality of their training. It is known that the quality of training of graduates of the College depends not only on the theoretical knowledge acquired in school, but also from industrial practice of students, organized at workplaces in real production conditions.

The mechanisms of dual training have provided a new approach in addressing this issue. And here we pay special attention to the creation of pupils, equipping them with modern equipment, as well as the selection of managers and instructors of production training of the most qualified professionals.

One of the important tasks that we set for ourselves, and probably the most important one is that for operation under the dual system required a reorientation, retraining (or training) as teachers in the College, and personnel at the enterprises. The footage will participate in the training process of highly skilled workers or specialists for specific jobs. The footage must be able to work in a completely new environment, and new technologies with a completely new quality ${ }^{\underline{40}}$.

And, since 2012, we have introduced a new system of training teachers of special subjects in manufacturing, increasing the duration of the internship from one to three months and consider each specific case on the possibility of admission of teacher trainee to the production cycle.

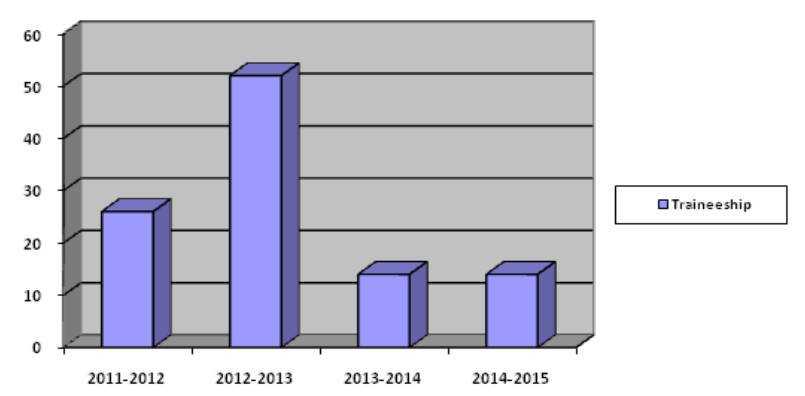

Picture 1. Traineeship

Equally important is the question of implementation of dual education is the provision of educational material resources.

To this end, the College modernized workshops, laboratories, as close to the conditions of modern production. This question is one of strategic directions of development of the College in the near future ${ }^{41}$. We consider the possibility of equipping laboratories and classrooms through multi-channel financing. First, through budgetary financing, and today, thanks to this we have a nice computer Park. Working places of teachers are equipped with personal computers and peripherals (printers, scanners) required software. Despite ICTs adoption in education, mostly higher institutions and colleges of learning deploy the use of such facilities without relevant policies guide showing how, what, where and when these facilities are going to be utilized ${ }^{42-46}$.

All units of the College are connected to the Internet there are cabinets with an interactive whiteboard. In additions opened new laboratories in the specialties of dual training Figure 5-6. In equipping teaching laboratories, neither workshop nor can we do without the help of our social partners, we have asked the enterprises to transfer to the College equipment for practical training. 

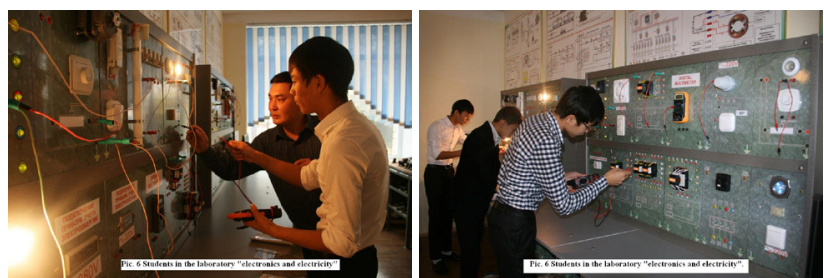

Figure 5. Laboratory of specialty "operation of oil and gas fields".

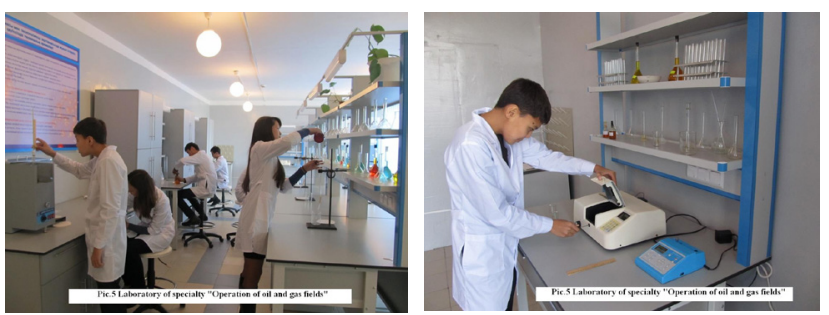

Figure 6. Students in the laboratory "electronics and electricity".

For the first time in 2013 in Balkhash town on the I National workshop on the dual system of education, we presented the experience of our institution on the implementation of the Pilot project on introduction of dual training.

In ${ }^{47}$ 2014, in Shymkent, at the II Republican seminar-meeting, we spoke about the experience of implementing the dual education system in 2014 in Astana, in the Corporate University "Samruk-Kazyna" took part at the round table "Introduction of dual training system: the Replication of best practices".

\section{Conclusions}

The widespread introduction of dual training is obvious and necessary due to the fact that the economy of the country requires qualified specialists of working professions, and therefore, all the forces of the MES aims at the implementation of the project. Summing up the work, it should be noted that in the field of dual training is implemented, employers and heads of educational institutions are ready to cooperate. The experience of our College and the experience of European countries show that we are moving in the right direction.

Thus, on the basis of research the following conclusions were made: firstly, the concept of the dual system of vocational education different from the traditional strengthening the practical orientation of training specialists;

secondly, the proposed system provides training of highly qualified specialists, demanded by the enterprises of various spheres of activity;

third, the dual system is an efficient mechanism to develop competence that will ensure an informed choice of profession; and

fourthly, this system will ensure the highest rate of graduate employment, as they fully meet the requirements of the employer.

The experience of College during this period received a positive evaluation from the leaders of core enterprises and the wider teaching community region, and the results of institutional accreditation by Independent Kazakhstan Agency for quality assurance in education, is a positive assessment of the expert group. In addition, in terms of rating estimation of activity of organizations of technical and vocational education in the region in 2014, the College took first place, and in 2015 based on results of multidisciplinary colleges of Kazakhstan, conducted by the Independent Kazakhstan Agency for quality assurance in Education College took second place.

\section{References}

1. Ishanov P, Bekmambetova Z. Requirements for the Content of Teaching Materials for Specialists' Training in Secondary Vocational Education, European Researcher. 2013; 54:7-1.

2. Mukhamadeyeva RM, Mukhamadeyev TM, Mukhamadeyeva IA. Structural and Logical Approach to the Introduction of Dual Training in Vocational and Technical Education System of the Republic of Kazakhstan, Indian Journal of Science and Technology. 2015 Dec; 8(S10):1-8.

3. Dietrich H. Integrating Young People into the Labour Market: Apprenticeship Training and Pre-Training Courses, Paper Prepared for the Peer Review on 'The Dual Training System - Integration of Young People into the Labour Market'; 2012. p. 1.

4. Otero M. Can results be the same when everything else is Different Dual Training in Spain, Paper Prepared for the Peer Review on The Dual Training System - Integration of Young People into the Labour Market, Germany, 2012.

5. The State Program of Education Development of the Republic of Kazakhstan for Approved by the Decree of the President of the Republic of Kazakhstan. Date accessed: 7/12/2010. www.akorda.kz/upload/SPED.doc. 
6. Gileva N. Dual Training as a Basis of Professional Education [Text], N. Gileva, Human Resources, Labour, Management in Organizations. 2015; 2:2-7.

7. Diane-Gabrielle Tremblay and Irene Le Bot the German Dual Apprenticeship System Analysis of its Evolution and Present Challenges, 2003.

8. Violaine. Pierre Initial Vocational Training and Youth Transition: A Comparative Analysis in France and Germany, 2012.

9. The Materials of the Online Conference on the Theme Modernization of the Education System - the Main Vector of Qualitative Growth of Human Potential. Date accessed: 12/09/2012. www.inform.kz/eng/article/249407.

10. Xu M. Development of Dual Educational System of Germany in China. Advanced Technology in Teaching, AISC. 2013; 163:289-93.

11. Anikeev AA, Arthur EA. The Modern Structure of the German Education, Alma Mater. 2012; 3:67-68.

12. Jeglinski N. Dual Education: Germany's Latest Export Hit. Date accessed: 09/07/2013. http://jewish-voice-from-germany.de/cms/dual-education-germanys-export-hit/.

13. Cockrill A. Vocational Education and Training in Germany: the Dual System and Stage Training Centre for Advanced Studies in the Social Sciences, University of Wales, 33 Corbett Road, Cardiff CF1 3EB, School of Education, University of Wales, 21 Senghennydd Road, Cardiff CF2 4YB, 1997.

14. Cantor L. Vocational Education and Training in the Developed World: a Comparative Study. London, New York: Routledge, 1989.

15. Ilyaschenko DP. The Main Aspects of the Organization of Internship and Employment of Students of the Department of Welding Production YUTI TPU, Internet Journal of the Sociology of Science. 2014; 1(20):16.

16. Dual Training - An Attractive System of Technical and Vocational Education. Date accessed: 16/03/14. http:// pedagog.kz.

17. The State Program of Education Development of the Republic of Kazakhstan for Approved by the Decree of the President of the Republic of Kazakhstan. Date accessed: 7/12/2010. www.akorda.kz/upload/SPED.doc.

18. Bilimal. 2010. http://old.bilimal.kz/.

19. Lucas Nulle. 2009. http://edulab.kz/info/katalogi/lucasneule.php.

20. ReferNet Spain - National Public Employment Service. Spain. Vocational Training in Europe - Country Report. Date accessed: 10/2010. https://www.sepe.es/contenidos/ personas/formacion/refernet/.../InformeFP2013-EN.pd...

21. The Message of the President of RK N.A. Nazarbayev Kazakhstan in the New Global Reality: Growth, Reforms and Development. Date accessed: 30/11/2015. www. akorda.kz/...kazakhstan/.../state-of-the-nation-address-bypresident-of-kazakhsta.

22. The Message of the President of the Republic of Kazakhstan - Leader of Nation to people of Kazakhstan Kazakhstan's way -Common Goal, Common Interests, Common Future. Date accessed: 17/01/2014. https://strategy2050.kz/en/ news/5714.

23. Euler D. Germany's Dual Vocational Training System: a Model for other Countries. 2013, p. 1-78.

24. Dual Training Implementation Guidebook, 2012-2014, p. 18.

25. Teshev VA. Dual Education as a Factor of Modernization of the System of Social Partnership of Universities and Enterprises, Vestnik of Adyghe State University. 2014; 1(135):139-44.

26. Othman A, Abdullah NH, Sulaiman M, Shamsuddin A. The Emerging Roles of Coaches in the National Dual Training System, Skills Malaysia Journal. 2015; 4(1):1-8.

27. Janagam D, Suresh B, Nagarathinam S. Efficiency of Task Based Learning and Traditional Teaching on Self-regulated Education, Indian Journal of Science and Technology. 2011 Mar; 4(3):1-5.

28. Anikeev AA, Arthur EA. The Modern Structure of the German education, Alma Mater. 2012; 3:67-68.

29. Dual Training at a Glance - An Illustrated Introduction (additional information) by BMBF, 2014, p. 1-41.

30. Hafner N. And Priority Directions of Methodical Work in the Conditions of Transition to Dual Training [Text], N. and Hafner, Technical and Professional Education. 2014; 2:39.

31. Zholdasbekov SA, Baltes PN. The Dual form of Education as an Alternative to the Professional Preparation of Teachers: Article, Shymkent. 2014.

32. Abzhapparov AA. Development of Dual Education System in Kazakhstan, Magazine Bilim. 2014; 2:13-14.

33. Ashimova DA. The Relevance of the Introduction of the Dual System of Education for Artistic Professions in Kazakhstan, Pedagogics and Psychology: Problems and Solutions: Mater. Intern. the Highest Level. Scientific.Pract. Conference Novosibirsk: Publishing House Sibak, 2013, p. 71-77.

34. Bozumbaev DB. Status and Prospects of Development of System of Professional Development of Teachers, Technical and Vocational Education in the Conditions of Introduction of the Dual Education System Management in Education. 2015; 2:10-14.

35. Teshev VA. Dual Education as a Factor of Modernization of the System of Social Partnership of Universities and Enterprises, Vestnik of Adyghe State University. 2014; 1(135):139-144.

36. The State Program of Education Development of the Republic of Kazakhstan for Approved by the Decree of the 
President of the Republic of Kazakhstan. Date accessed: 7/12/2010. www.akorda.kz/upload/SPED.doc.

37. Hercz M, Koltoi L, Rigo R. Competences for the Success of Students Learning in Dual Training System: The Firm's Voice, 6th International Scientific and Expert Conference TEAM, 2014 Nov. p. 10-11.

38. Teshev VA. Dual Education as a Factor of Modernization of the System of Social Partnership of Universities and Enterprises, Vestnik of Adyghe State University. 2014; 1(135):139-44.

39. Kamerbaev A, Yu, Kashuk LI. For Training the New Formation, Modern Education. 2012; 2(86):55-57.

40. Ibid.

41. Abzhapparov AA. Development of Dual Education System in Kazakhstan, Magazine Bilim. 2014; 2:13-14.

42. Shu'aibu B, Saud MSB, Bello H, Kamin Y, Buntat Y. Modelling the Determinants of ICTs Policy Formulation in Technical and Vocational Education in Nigerian Institution of Higher Learning, Indian Journal of Science and Technology. 2013 Apr; 6(4):1-9.

43. Gorokhova N. According to the Dual Model Urals. 2013 Apr; 37:17.

44. Ivanova S. Vet and Business: Dialogue of Partners [Text], C. Ivanova, The Class Time. 2012 Dec; 46:5.

45. Kuzembayev SB. Prospects of Dual Education, Magazine Bilim. 2012; 3(3):33-37.

46. Kashuk LI. An Adapted Model of the Dual Technology [Text], L.I. Kashuk, Accreditation in Education. 2015; 6:50-52.

47. Jeglinski N. Dual Education: Germany's Latest Export Hit. Date accessed: 09/07/2013. http://jewish-voice-from-germany.de/cms/dual-education-germanys-export-hit/. 